\title{
Report of the Korean Association of External Quality Assessment Service on Cardiac Marker Testing (2016-2020)
}

\author{
Jong Do Seo ${ }^{1 \oplus}$, Hanah $\mathrm{Kim}^{1,2}{ }^{\oplus}$, and Yeo-Min Yun ${ }^{1,2}$ \\ ${ }_{1}^{1}$ Department of Laboratory Medicine, Konkuk University Medical Center; 2Department of Laboratory Medicine, Konkuk University \\ School of Medicine, Seoul, Korea
}

\section{Corresponding author:}

Yeo-Min Yun

Department of Laboratory Medicine, Konkuk University Medical Center, Konkuk University School of Medicine, 120-1 Neungdong-ro, Gwangjin-gu, Seoul 05030, Korea

Tel +82-2-2030-5582

E-mailymyun@kuh.ac.kr
This is an Open Access article distributed under the terms of the Creative Commons Attribution Non-Commercial License (http://creativecommons.org/licenses/ by-nc/4.0) which permits unrestricted non-commercial use, distribution, and reproduction in any medium, provided the original work is properly cited.
Cardiac marker tests are useful tools to diagnose acute coronary syndrome and predict its prognosis; therefore, reliable test results are required. The Korean Association of External Quality Assessment Service has conducted a proficiency test program for cardiac marker tests twice a year since 2016 using low- and medium-level pooled serum and high-level commercial quality control (QC) material. This report summarizes the results of the proficiency tests performed from 2016 to 2020. The number of participating laboratories increased from 321 in 2016 (1st trial) to 476 in 2020 (2nd trial). Items that showed the highest increase in participation during this period were tests for $\mathrm{N}$-terminal-pro brain natriuretic peptide (NT-proBNP) (+86.2\%) and creatine kinase-myocardial band (CK-MB) mass tests $(+73.2 \%)$, whereas the corresponding BNP $(-6.6 \%)$ and CK-MB activity $(-26.5 \%)$ items were decreased. The most and least commonly tested items were CK-MB mass in 417 laboratories, and CK-MB activity in 25 laboratories, respectively. The coefficients of variation (CVs) differed among the manufacturers, and among different instruments from the same manufacturer. In 2020, during the 2nd trial, the lowest $\mathrm{CV}$ was confirmed in the troponin $\mathrm{T}$ test using the same manufacturer's instruments, for the medium-level pooled serum sample. However, the CV for high-level commercial QC material was higher. Similarly, the NT-proBNP test for commercial QC material showed higher CV compared to pooled serum. These results are considered to originate from the non-commutability of commercial QC material; therefore, obtaining the commutability of the materials for the external quality assessment program is required.

(Lab Med Qual Assur 2021;43:176-84)

Key Words Cardiac marker, External quality assessment, Commutability

\section{서론}

급성관상동맥증후군(acute coronary syndrome, ACS)은 빠 른 진단이 예후에 큰 영향을 미치며, 감별 진단에는 심장표지자 (cardiac marker)검사가 매우 중요하다. 미국심장협회의 진료지 침에 따르면 $\mathrm{ACS}$ 가 의심되는 환자에서 증상 발현 6 시간 이내에
심장 트로포닌 검사를 시행하여 농도를 확인하고, 초기 검사에서 정상 농도를 나타낸 환자에서 심전도의 변화가 관찰되거나 ACS 관련 임상증상이 발생한 경우 증상 발현 6시간 이내에 추가 검사 를 시행하여 ACS 진단에 활용할 것을 권고하고 있다. 또한 급성심 근괴사 진단 시에는 트로포닌 최고농도뿐만 아니라 연속적인 변 화에 대한 평가의 시행을 권고하는데, 초기 측정 농도가 참고치인 
99백분위수 상한값보다 높으면서 추가 측정에서 연속으로 농도의 증가가 관찰되거나 $20 \%$ 이상의 급격한 감소가 보이는 경우, 혹은 초기 측정 농도가 참고치보다는 낮거나 근접하다가 추가 측정에서 검사실 표준편차의 3 배 이상 변동을 보이는 경우 급성심근괴사를 진단할 수 있다[1].

따라서 ACS 및 급성심근괴사를 진단할 때 심장표지자검사의 참 고치에 해당하는 저농도에서의 검사 민감도와 정확도 확보가 중요 하며, 외부정도관리 프로그램을 통하여 임상검사실의 심장표지자 검사 능력을 평가하는 것은 심장질환 임상진료의 질 향상을 위하 여 매우 중요하다.

대한임상검사정도관리협회는 2015년까지 운영해오던 분과 프 로그램의 운영을 2016년도부터 차세대 신빙도조사사업 체계로 변경 출범하면서 심장표지자단백검사에 대한 신빙도조사를 임상 화학 대분류의 단백검사 중분류 아래의 소분류 항목으로서 협회의 정규프로그램으로 집행하고 있다. 현재 심장표지자단백검사에는 9종의 검사항목이 포함되어 있다. 저자들은 본 보고서에서 2016 년도부터 2020년까지 실시되었던 심장표지자단백검사의 신빙도 조사 결과를 분석하여 보고하고자 한다.

\section{재료 및 방법}

\section{1. 정도관리물질}

심장표지자단백검사 프로그램에서는 상반기와 하반기로 나누 어 연간 2 회에 걸쳐 회차별, 항목별로 3 개 농도의 정도관리물질을 이용하여 신빙도조사를 실시하고 있으며, 정도관리물질로는 저농 도, 중간 농도의 자가제조물질과 고농도의 상용화 물질이 사용되 고 있다.

심장표지자단백검사 프로그램 평가용의 저농도, 중간 농도 자 가제조물질은 Clinical and Laboratory Standards Institute (CLSI) C37-A 지침을 기반으로 잔여 검체 혼합 혈청(pooled serum)에 고농도 심장표지자단백 잔여 혈청 검체를 첨가 (spiking)하여 제조하였다[2]. 첨가 검체는 신빙도조사에 포함된 심장표지자단백 항목에 대한 임상검사가 의뢰되어 고농도의 측정 결과가 확인된 환자의 잔여 혈청 검체를 별도로 수집하여 냉장보 관하였던 것을 사용하였다. 혼합 혈청에 고농도 잔여 혈청 검체를 첨가한 후 $4^{\circ} \mathrm{C}$ 냉장실에서 교반기를 이용하여 16 시간 이상 혼합 하고, 혼합물을 $3,000 \mathrm{rpm}$ 에서 10 분간 원심분리 시행한 후 0.2 $\mu \mathrm{m}$ 필터를 통하여 잔여 침전물을 제거하여 제조한 저농도와 중간 농도의 외부정도관리물질을 농도별로 각각 $1 \mathrm{~mL}$ 바이알에 분주 하여 냉동보관하였다.

고농도 외부정도관리물질은 상용화 물질인 Seronorm Cardiac Acute Liq (SERO AS Stasjonsveien 44, NO-1396;
SERO AS, Billingstad, Norway)를 이용하였으며, 신빙도조사사 업 각 회차마다 상술한 2개 농도의 자가제조물질과 상용화 물질 1 개로 평가물질 세트를 구성하여 심장표지자단백검사 프로그램 참 가기관에 발송하였다.

\section{2. 신빙도조사 심장표지자 종목}

2016년도부터 2020년도까지 시행한 대한임상검사정도관리 협회의 심장표지자단백검사 신빙도조사에 포함된 심장표지자 종 목은 troponin I ( $\mathrm{Tnl}$ ), troponin $\mathrm{T}$ ( $\mathrm{TnT}$ ), creatine kinase-MB (CK-MB) activity, CK-MB mass, myoglobin, brain natriuretic peptide (BNP), N-terminal pro-brain natriuretic peptide (NT-proBNP), high-sensitivity C-reactive protein (hs-CRP), homocysteine으로 5년간 1 회차와 2회자 모두 동일한 종목을 대 상으로 신빙도조사를 시행하였다.

\section{3. 결과분석 및 판정}

신빙도조사 평가물질은 택배를 이용하여 참가기관에 발송하였 고, 각 기관에서 입력한 결과는 전체 참여기관, 장비 제조회사별, 측정 기기별로 입력된 결과에 대하여 통계분석을 시행하였고 참 가기관에는 개별기관의 평가결과를 정리한 기관별 보고서와 프 로그램 참여기관 전체의 결과를 정리한 공통 보고서가 제공되었 다. 공통 보고서에는 평가종목별로 전체 참여기관(all), 장비 제조 사에 기초한 기준분류, 측정기기에 기초한 세분류에 따라 참여기 관의 수 $(\mathrm{N})$, 측정값의 평균(mean), 측정값의 표준편차(standard deviation), 변이계수(coefficient of variation, CV), 중간값 (median), 최소값(min), 최대값(max)을 제시하였다. 범용 장비 와 범용 시약을 사용하는 검사시스템의 기준분류는 2019년도 1차 신빙도조사까지는 장비 제조사를 기준으로 분류하였으나 2019년 도 2차 신빙도조사부터는 시약 제조사를 기준으로 하는 분류로 변 경되었다.

평균, 표준편차, 변이계수는 분류별 분석에서 75 백분위수의 값 (Q3)과 25백분위수의 값 $(\mathrm{Q} 1)$ 사이의 차이값(Q3-Q1; 사분위수 범위, interquartile range, IQR)의 1.5 배를 초과하여 Q1보다 작 거나 Q3보다 큰 결과값(<Q1-1.5 $\times 1 \mathrm{QR}$ or $>\mathrm{Q} 3+1.5 \times \mid \mathrm{QR})$ 을 이 상치로 간주하여 제거한 후 분석한 값을 제시하였고 중간값, 최소 값, 최대값은 이상치를 제거하지 않고 해당 분류에 속한 기관을 모 두 포함하여 제시하였다.

분류에 속하는 기관 수가 10 개 이상이면서 이상치 제거 후 남은 값이 8 개 이상인 경우에는 상술한 지표를 모두 보고서에 제시하였 고, 참여기관이 10 개 미만이거나 이상치 제거 후 남은 값이 8 개 미 만인 경우는 평균, 표준편차, 변이계수를 제시하지 않고 중간값, 최소값, 최대값만을 표기하였다. 참여기관이 2 개인 경우는 중간값 
을 제시하지 않고 낮은 측정값과 높은 측정값을 각각 최소값과 최 대값으로 제시하였으며, 기관 수가 1 개인 경우는 2017년도까지의 공통 보고서에는 포함되지 않았으나 2018년도부터의 공통 보고 서에는 포함되어 입력된 값을 중간값으로 보고하였다.

기관별 보고서에는 각 기관의 입력결과를 바탕으로 기준분류 및 세분류에 대하여, 상술한 평균 및 표준편차 제시조건을 충족하 는 경우 표준편차지수(standard deviation index, SDI)를 함께 제시하였고, 기준분류 및 세분류의 SDI값이 \pm 3 이내인 경우를 적 합(acceptable)한 것으로 판정하였다.

\section{결과}

\section{1. 신빙도조사 참여기관}

2016년도 1회차부터 2020년도 2회차까지 심장표지자단백 신 빙도조사사업에 참여하여 결과를 회신한 기관의 수는 321 개 기관 에서 476개 기관으로 증가하였으며, 회신율은 97.5\%-99.8\%였 다. 2016년도 1 회차 심장표지자단백검사 프로그램은 324 개 기관 에 검체를 발송하여 321개(99.1\%) 기관에서 회신하였으며 2020 년도 1 회차 프로그램은 473 개 기관에 검체를 발송하여 468 개 기 관(98.9\%)에서 회신하였고, 2 회차에 477 개 기관에 검체를 발송 하여 476 개 기관(99.8\%)에서 회신하였다.

Table 1 에 각 검사항목별 신빙도조사 참여기관과 함께 10 개 이 상의 기관이 포함된 주요 기준분류의 수를 표시하였으며, 2016년 도 1 회차와 비교하여 2020년도 2 회차 참여기관 수의 변화를 살펴 보았을 때 NT-proBNP (+86.2\%), CK-MB mass (+73.2\%) 항목 에 대한 참여기관의 증가가 두드러졌으며, 각각에 대응하는 BNP (-6.6\%), CK-MB activity (-26.5\%) 항목은 참여기관 수에 감소 가 있었다. 나머지 5 개 평가항목에 대해서는 $+4.5 \%$ 에서 $+44.3 \%$ 의 참여기관 증가가 확인되었다. 2020년도 2회차의 심장표지자단 백검사 프로그램에서 가장 많은 기관이 참여한 심장표지자 종목은 CK-MB mass로 417 개 기관에서 참여하였으며 가장 적은 기관이 참여한 종목은 25 개 기관에서 참여한 CK-MB activity였다.

\section{2. 신빙도조사 결과보고에 사용된 장비}

심장표지자단백검사 신빙도조사 결과의 보고에는 대부분의 참가기관에서 면역측정장비를 사용하였으며, CK-MB activity, hs-CRP, homocysteine 등의 검사종목의 경우 일부 참가기관 에서 일반화학측정장비를 사용하여 결과를 보고하였다. Table 1 에 표시된 바와 같이 장비 제조사별 기준분류에서는 Roche (Mannheim, Germany) 검사장비를 사용하는 참가기관이 가장 많았고, Abbott (Abbott Park, IL, USA), Siemens (Tarrytown, NY, USA), Beckman Coulter (Brea, CA, USA), Radiometer
(Brønshøj, Denmark) 검사장비도 다수의 참가기관에서 사 용하고 있었다. 2020년도 2회차의 신빙도조사사업을 기준으 로, 총 9 개의 심장표지자단백검사 항목 중 TnT, CK-MB mass, myoglobin, NT-proBNP, homocysteine 등 5 개 검사항목에 대 해서는 Roche 장비를 사용하는 기관이 가장 많았고, Tnl, BNP 등 2개 검사항목에서는 Abbott 장비, CK-MB activity, hs-CRP 등 2 개 검사에서는 범용 장비를 사용하는 기관이 가장 많았다.

신빙도조사사업 초기부터 동일한 범용 장비와 범용 시약을 사 용하여 지속적으로 참여한 기관의 경우 상술한 2019년도 2회차의 기준 변경에 따라 기준분류 및 세분류의 변화가 있을 수 있다.

\section{3. 신빙도조사 결과의 통계}

2020년도 2회차의 심장표지자단백검사의 검사항목별, 정도관 리물질 농도별 분석결과를 평균과 표준편차, 변이계수의 산정이 가능하였던 주요 세분류를 대상으로 Table 2 와 같이 정리하였다. 전체 참가기관에 대하여 가장 작은 검사실 간 변이계수를 보인 검 사항목은 TnT 검사항목의 CCA-20-05 물질이었으며(3.6\%), 이 는 해당 검사항목의 경우 모든 참가기관이 동일 제조사(Roche) 의 검사장비를 사용하기 때문인 것으로 생각되었다. 반면에 다양 한 제조사의 장비를 사용하는 기관이 참가한 $\mathrm{Tnl}$ 검사항목의 경우 3 개 농도의 평가물질 세트에 대하여 전체 참가기관 간에 $51.6 \%$ $77.1 \%$ 의 큰 변이계수를 보였다.

2016년도 1회차부터 2020년도 2회자까지 10회에 걸친 신빙도 조사사업에서 중간 농도 자체 제조 평가물질과 고농도 상용화 평 가물질에 대한 검사항목 $\mathrm{Tnl}, \mathrm{TnT}, \mathrm{BNP}, \mathrm{NT}$-proBNP의 주요 기 준분류 별 변이계수 추이는 Fig. 1 에 나타낸 것과 같다. 일부 기준 분류에서 Q1과 Q3이 동일한 특정 값인 경우, 기준에 따라 해당 값 이외의 입력결과는 이상치로 분류되어 제거되었으며 표준편차와 변이계수는 0 으로 계산되었다.

\section{고찰}

2020년도 2회차의 심장표지자단백검사 신빙도조사사업에서 $\mathrm{TnT}$ 검사항목의 CCA-20-05 물질에서 $3.6 \%$ 로 가장 작은 변이계 수를 나타냈고, 이는 모든 참가기관이 동일 제조사의 장비를 사 용하기 때문인 것으로 생각되었다. 단, 고농도 표준물질인 CCA20-06의 검사에서는 동일 제조사의 장비를 사용함에도 불구하 고 $31.7 \%$ 의 높은 변이계수를 나타냈는데, 이는 세분류상 cobas 4000 장비에서 다른 장비에 비하여 유의하게 낮은 측정값을 나 타낸 것이 원인인 것으로 생각되었다. NT-proBNP의 측정에서 도 고농도 표준물질에서 저농도 및 중간 농도 표준물질에 비하여 높은 변이계수를 보이는 양상이 확인되었으며(52.1\% vs. 5.2\%- 


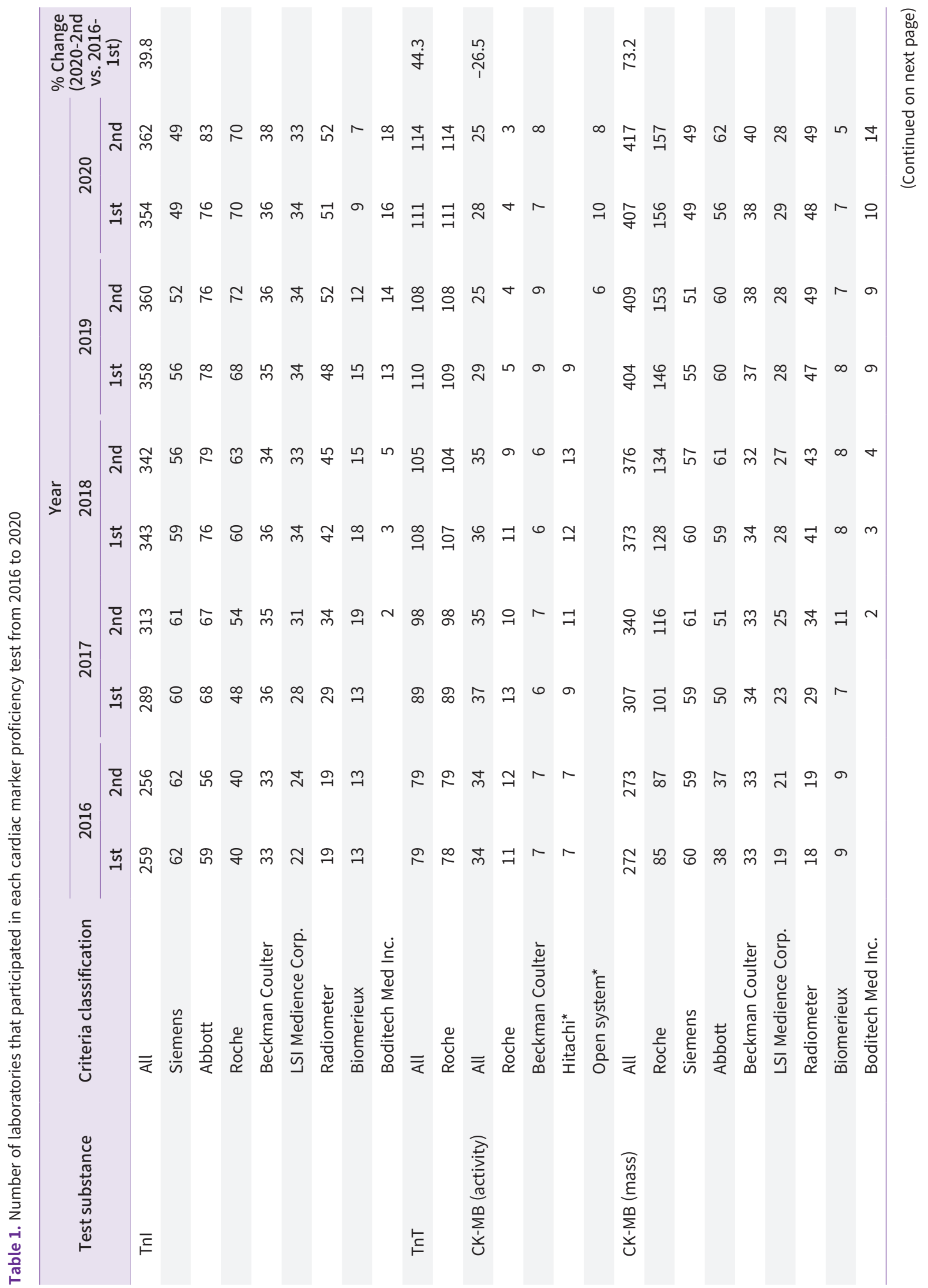




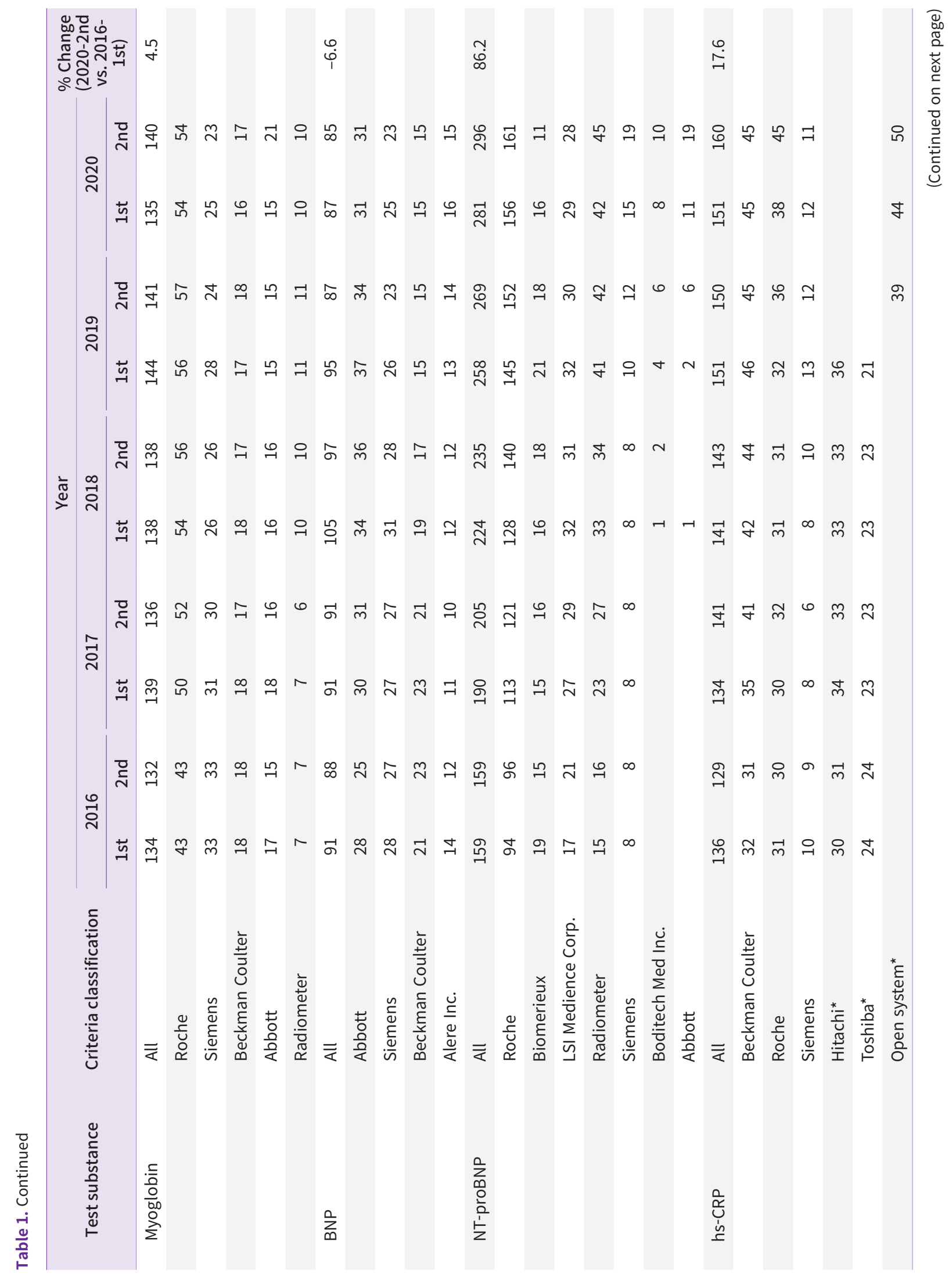




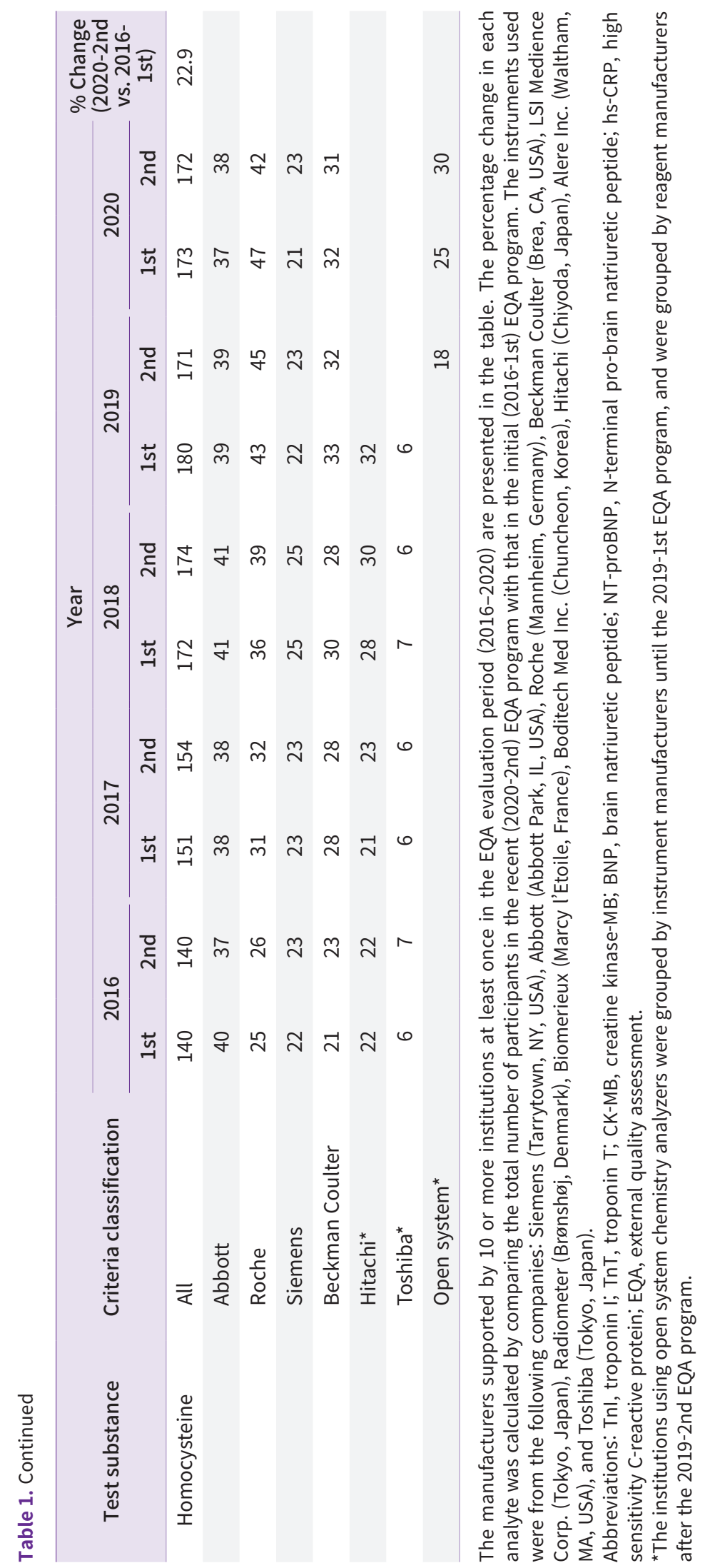


Table 2. Results of cardiac marker proficiency test for subgroups during the 2020-2nd EQA program

\begin{tabular}{|c|c|c|c|c|c|c|c|c|}
\hline \multirow{2}{*}{$\begin{array}{c}\text { Test } \\
\text { substance }\end{array}$} & \multirow{2}{*}{ Instrument } & \multirow{2}{*}{$\begin{array}{l}\text { No. of } \\
\text { labs }\end{array}$} & \multicolumn{2}{|c|}{$\begin{array}{l}\text { CCA-20-04 (pooled } \\
\text { human serum) }\end{array}$} & \multicolumn{2}{|c|}{$\begin{array}{l}\text { CCA-20-05 (pooled } \\
\text { human serum) }\end{array}$} & \multicolumn{2}{|c|}{$\begin{array}{l}\text { CCA-20-06 (commercial } \\
\text { control material) }\end{array}$} \\
\hline & & & Mean $\pm S D$ & CV (\%) & Mean $\pm S D$ & CV (\%) & Mean $\pm S D$ & CV (\%) \\
\hline \multirow[t]{10}{*}{ Tnl } & All & 362 & $0.179 \pm 0.138$ & 77.1 & $0.227 \pm 0.174$ & 76.8 & $5.220 \pm 2.696$ & $51.6^{\star}$ \\
\hline & ADVIA Centaur XPT & 12 & $0.362 \pm 0.029$ & 8.1 & $0.468 \pm 0.038$ & 8.0 & $17.602 \pm 0.671$ & 3.8 \\
\hline & ARCHITECT i1000 & 22 & $0.360 \pm 0.026$ & 7.1 & $0.452 \pm 0.033$ & 7.3 & $7.359 \pm 0.549$ & 7.5 \\
\hline & ARCHITECT i2000 & 56 & $0.365 \pm 0.024$ & 6.7 & $0.452 \pm 0.03$ & 6.7 & $7.142 \pm 0.435$ & 6.1 \\
\hline & UniCel DxI800 & 34 & $0.022 \pm 0.002$ & 10.0 & $0.026 \pm 0.002$ & 9.2 & $5.253 \pm 0.196$ & 3.7 \\
\hline & Pathfast & 33 & $0.051 \pm 0.007$ & 14.4 & $0.068 \pm 0.009$ & 13.9 & $4.839 \pm 0.507$ & 10.5 \\
\hline & AFIAS-6 & 17 & $0.175 \pm 0.015$ & 8.3 & $0.220 \pm 0.018$ & 8.2 & $9.704 \pm 0.835$ & 8.6 \\
\hline & AQT90 FLEX & 52 & $0.022 \pm 0.002$ & 8.2 & $0.026 \pm 0.003$ & 10.8 & $1.153 \pm 0.057$ & 5.0 \\
\hline & cobas4000 e411 & 41 & $0.164 \pm 0.032$ & 19.5 & $0.207 \pm 0.032$ & 15.5 & $3.945 \pm 0.332$ & 8.4 \\
\hline & cobas6000 e601 & 17 & $0.159 \pm 0.021$ & 13.2 & $0.200 \pm 0.024$ & 12.2 & $3.596 \pm 0.175$ & 4.9 \\
\hline \multirow[t]{5}{*}{ TnT } & All & 114 & $0.156 \pm 0.006$ & 3.7 & $0.197 \pm 0.007$ & 3.6 & $1.674 \pm 0.531$ & $31.7^{\star}$ \\
\hline & cobas e 801 & 29 & $0.157 \pm 0.005$ & 3.0 & $0.199 \pm 0.005$ & 2.5 & $2.116 \pm 0.162$ & 7.7 \\
\hline & cobas 4000 e411 & 51 & $0.156 \pm 0.006$ & 4.0 & $0.199 \pm 0.009$ & 4.4 & $1.124 \pm 0.129$ & 11.5 \\
\hline & cobas6000 e601 & 15 & $0.154 \pm 0.005$ & 3.3 & $0.196 \pm 0.007$ & 3.3 & $2.05 \pm 0.209$ & 10.2 \\
\hline & cobas 8000 e602 & 19 & $0.153 \pm 0.006$ & 3.7 & $0.194 \pm 0.005$ & 2.6 & $2.028 \pm 0.2$ & 9.9 \\
\hline \multirow[t]{4}{*}{ BNP } & All & 85 & NA & NA & NA & NA & $1,382.0 \pm 167.3$ & 12.1 \\
\hline & ARCHITECT i2000 & 23 & NA & NA & NA & NA & $1,414.4 \pm 143.6$ & 10.2 \\
\hline & UniCel DxI800 & 15 & NA & NA & NA & NA & $1,265.5 \pm 41.5$ & 3.3 \\
\hline & Triage Meter-pro & 15 & NA & NA & NA & NA & $615.4 \pm 109.5$ & 17.8 \\
\hline \multirow[t]{9}{*}{ NT-proBNP } & All & 296 & $6,295.9 \pm 360.3$ & 5.7 & $8,020.3 \pm 412.7$ & 5.2 & 4,604.6士2,399.0 & $52.1^{\star}$ \\
\hline & cobas e 801 & 38 & $6,042.1 \pm 162.9$ & 2.7 & $7,795.5 \pm 199.2$ & 2.6 & $3,287.5 \pm 122.7$ & 3.7 \\
\hline & cobas 4000 e411 & 68 & $6,282.7 \pm 228.1$ & 3.6 & $8,134.6 \pm 330.7$ & 4.1 & $2,705.3 \pm 161.5$ & 6.0 \\
\hline & cobas6000 e601 & 29 & $6,242.5 \pm 221.6$ & 3.6 & $7,922.2 \pm 225.4$ & 2.8 & $3,415.1 \pm 236.6$ & 6.9 \\
\hline & cobas8000 e602 & 26 & $6,158.7 \pm 183.8$ & 3.0 & $7,958.3 \pm 238.3$ & 3.0 & $3,425.1 \pm 240.4$ & 7.0 \\
\hline & Pathfast & 28 & $5,820.1 \pm 657.0$ & 11.3 & $7,588.7 \pm 712.5$ & 9.4 & $10,402.2 \pm 808$ & 7.8 \\
\hline & AQT90 FLEX & 45 & $6,462.3 \pm 250.2$ & 3.9 & $8,115.8 \pm 365.4$ & 4.5 & $6,767.2 \pm 291.2$ & 4.3 \\
\hline & AFIAS-6 & 10 & $6,623.4 \pm 540.9$ & 8.2 & $8,660.5 \pm 678.1$ & 7.8 & $20,055.5 \pm 1,957.2$ & 9.8 \\
\hline & ARCHITECT i2000 & 16 & 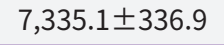 & 4.6 & $9,370.6 \pm 464.8$ & 5.0 & $4,120.6 \pm 232.2$ & 5.6 \\
\hline
\end{tabular}

The instruments used in 10 or more institutions during the 2020-2nd EQA program are presented in the table. The level of BNP, which in ethylenediaminetetraacetic acid-plasma is a suitable specimen recommended by the test manufacturer, was measured in commercial material only. The instruments used were from the following companies: Siemens (Tarrytown, NY, USA), Abbott (Abbott Park, IL, USA), Beckman Coulter (Brea, CA, USA), Polymedco (Cortlandt Manor, NY, USA), Boditech Med Inc. (Chuncheon, Korea), Radiometer (Brønshøj, Denmark), Roche (Mannheim, Germany), and Quidel Corp. (San Diego, CA, USA).

Abbreviations: EQA, external quality assessment; SD, standard deviation; CV, coefficient of variation; Tnl, troponin I; TnT, troponin T; BNP, brain natriuretic peptide; NA, not available; NT-proBNP, N-terminal pro-brain natriuretic peptide.

${ }^{*} \mathrm{CCA}-20-06$, the commercial control material with high concentration of cardiac marker, showed higher CV\% compared to other materials.

$5.7 \%)$, 해당 검사항목의 경우 기준분류 내의 측정값 차이는 크지 않은데 비하여 장비 제조사 간 차이가 크게 나타났다. 이는 CLSI 지침에 따라 교환 가능성(commutability)의 확보가 가능하도록
자체 제조한 저농도 및 중간 농도의 평가물질에 비하여 상용화 물 질인 고농도 평가물질의 경우 검사시스템 간 교환 가능성을 확보 하지 못하여 나타난 현상으로 추정되며, 외부정도관리를 시행할 
A Pooled serum

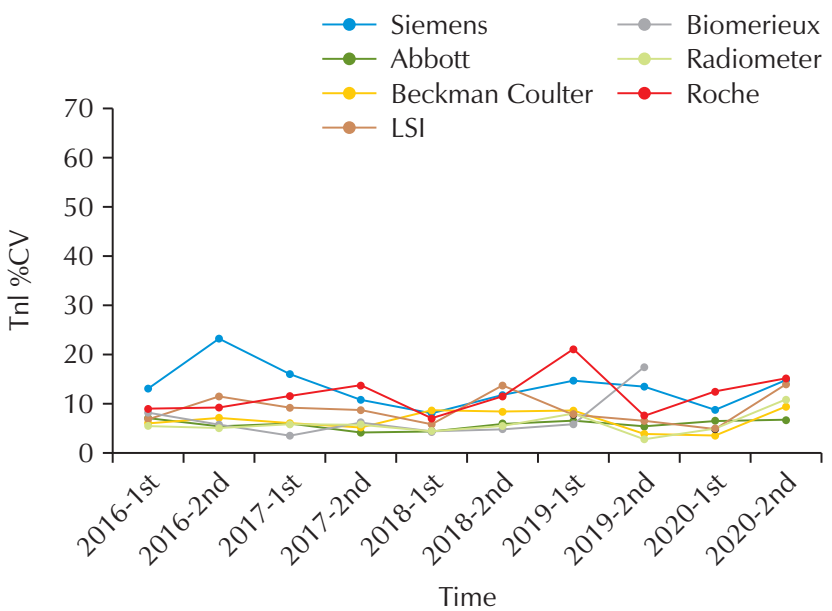

C Pooled serum

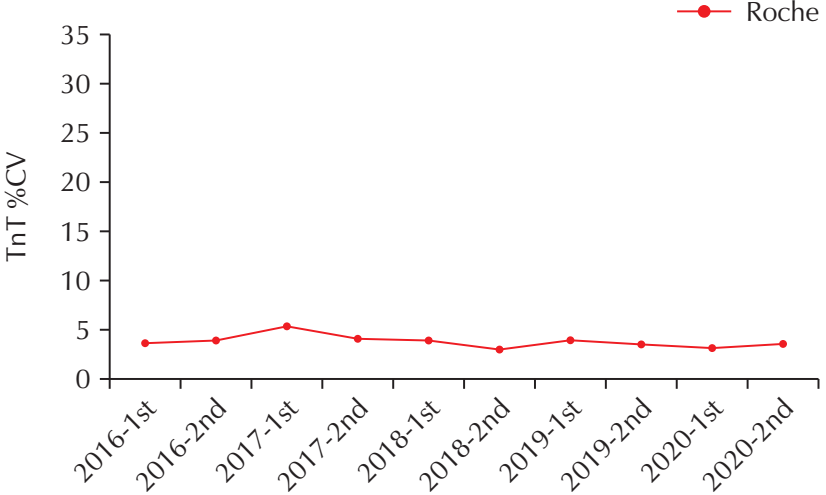

Time

E Pooled serum

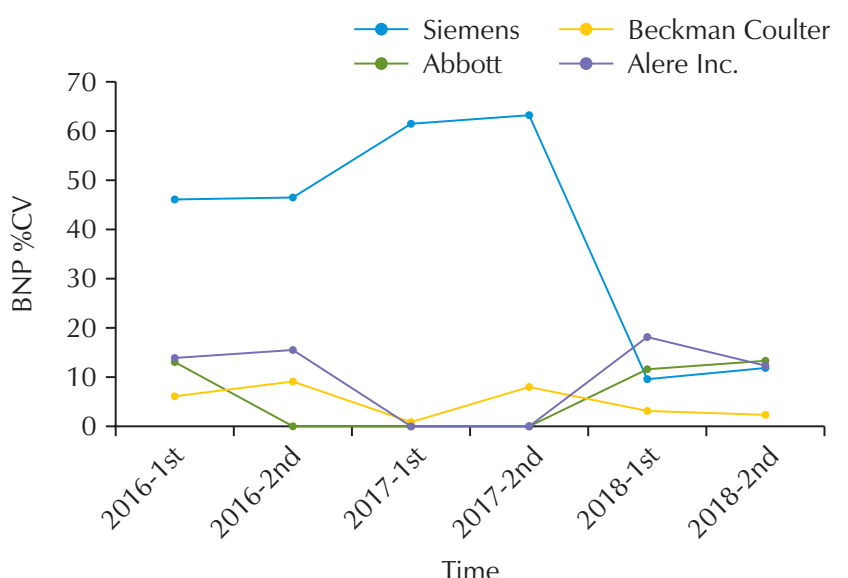

B Commercial control material

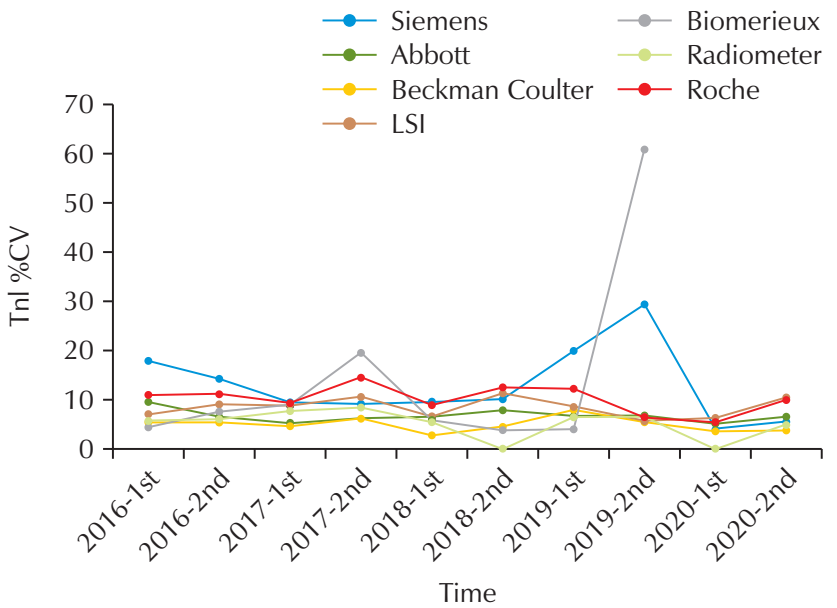

D Commercial control material

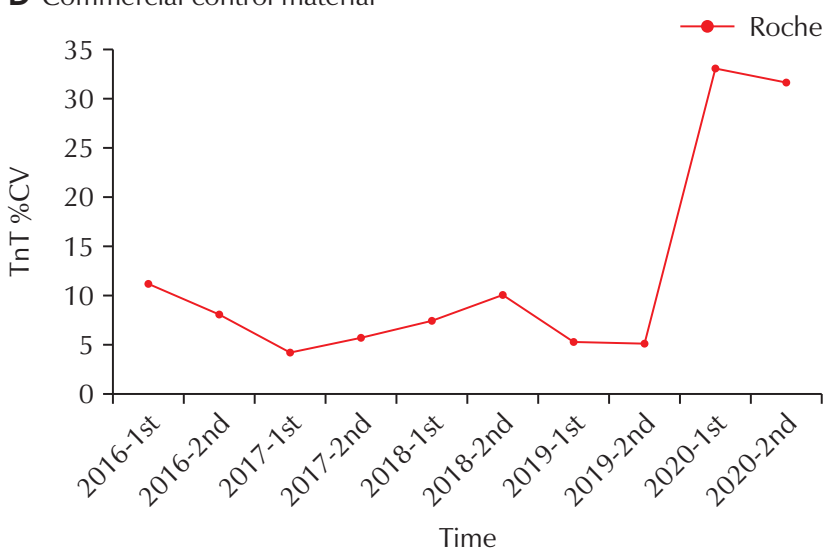

F Commercial control material

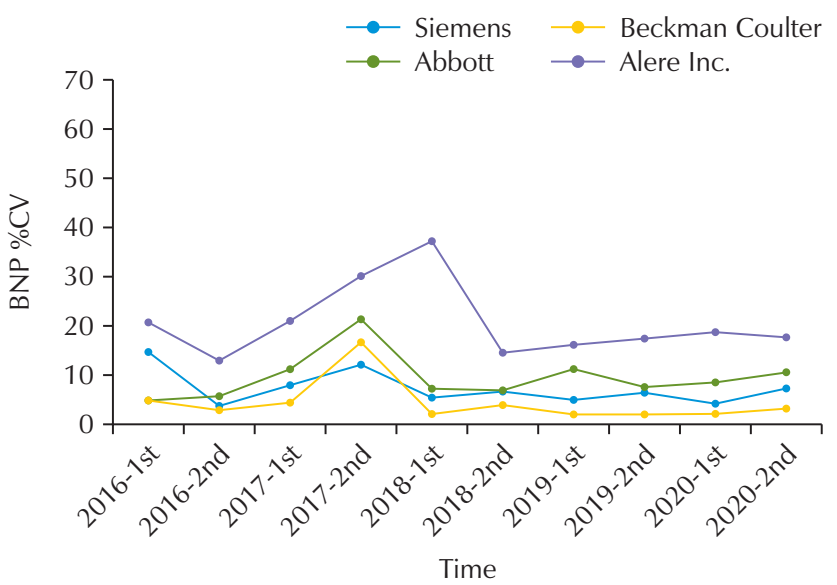

Fig. 1. Change in coefficient of variation \% during the period of cardiac marker external quality assessment program from 2016-1st to 2020-2nd for (A, B) troponin I (Tnl) in pooled serum and commercial control material, respectively. (C, D) Troponin T (TnT), (E, F) brain natriuretic peptide (BNP), and (G, H) N-terminal pro-brain natriuretic peptide (NT-proBNP) of each manufacturer. BNP test for the pooled serum sample has been discontinued since 2018 because ethylenediaminetetraacetic acid-plasma is the only suitable specimen recommended by the manufacturers. The instruments used were from the following companies: Siemens (Tarrytown, NY, USA), Abbott (Abbott Park, IL, USA), Beckman Coulter (Brea, CA, USA), LSI Medience Corp. (Tokyo, Japan), Biomerieux (Marcy l'Etoile, France), Radiometer (Brønshøj, Denmark), Roche (Mannheim, Germany), and Alere Inc. (Waltham, MA, USA) (Continued on next page). 


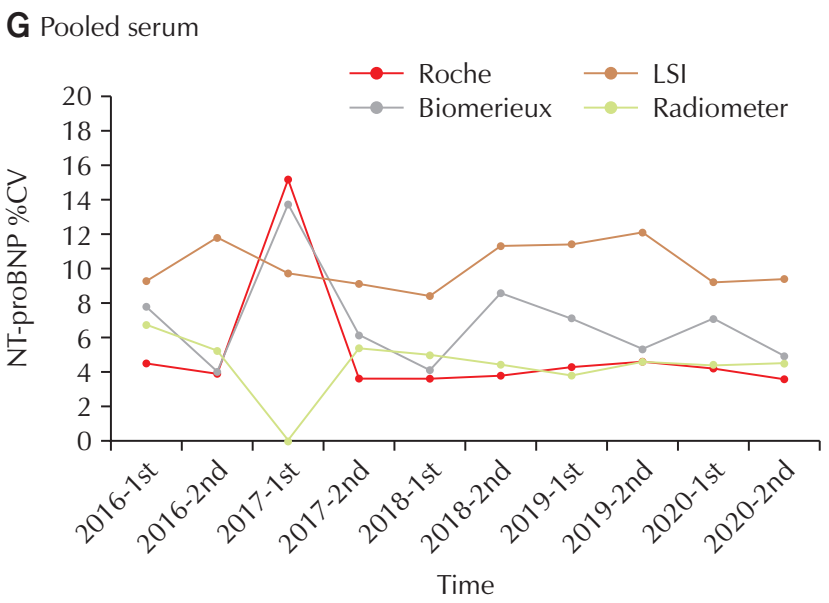

Fig. 1. (Continued; caption shown on previous page).

때 평가물질의 교환 가능성 확인에 유의할 필요가 있을 것으로 생 각된다.

3 개 농도의 평가물질 세트에 대하여 전체 참가기관 간에 큰 변 이계수를 나타낸 $\mathrm{Tnl}$ 검사의 경우, 동일한 검사기기를 사용하는 세분류 그룹의 변이계수는 cobas 4000 장비를 사용한 CCA-2004의 측정에서 최대 $19.5 \%$ 로 전체 기관간 변이계수에 비하여 작 아, 검사기기 간의 측정값 차이가 높은 변이계수에 크게 기여한 것 으로 판단되었다. 이는 참여기관의 검사 수행능의 차이에서 기반 한 영향보다는 각 검사실에서 사용하고 있는 검사의 면역측정 항 체의 특성이나 평가물질 기질에 대한 각 제조사 시약의 반응성 차 이(matrix effect)에 의한 결과로 추정된다.

이에 따라 향후의 심장표지자단백검사 신빙도조사사업에서는

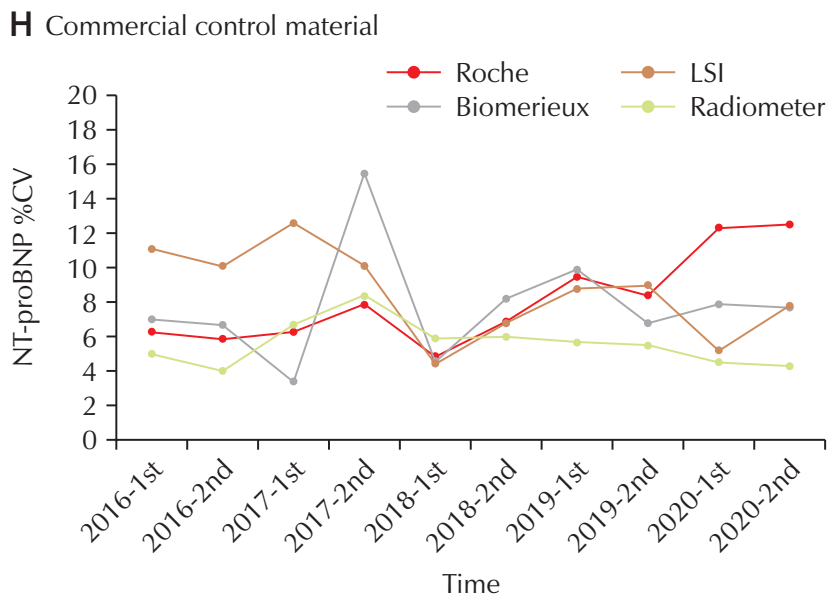

각 제조사의 검사방법 간의 기질효과를 최소화하여 임상검사실 심 장표지자검사의 신뢰도를 보다 정확하게 평가할 수 있도록, 평가 에 활용되는 자체 제조 표준물질과 상용화 표준물질을 대상으로 한 교환 가능성의 사전 평가를 검토할 필요가 있을 것으로 생각된 다[3].

\section{ORCID}

Jong Do Seo https://orcid.org/0000-0001-7449-7978

Hanah Kim https://orcid.org/0000-0002-3266-638X Yeo-Min Yun

\section{REFERENCES}

1. Amsterdam EA, Wenger NK, Brindis RG, Casey DE Jr, Ganiats TG, Holmes DR Jr, et al. 2014 AHA/ACC guideline for the management of patients with non-ST-elevation acute coronary syndromes: executive summary: a report of the American College of Cardiology/American Heart Association Task Force on Practice Guidelines. Circulation 2014;130:2354-94.

2. Danilenko U, Vesper HW, Myers GL, Clapshaw PA, Camara JE, Miller WG. An updated protocol based on CLSI document C37 for preparation of off-the-clot serum from individual units for use alone or to prepare commutable pooled serum reference materials. Clin Chem Lab Med 2020;58:368-74.

3. Clinical and Laboratory Standards Institute. Evaluation of commutability of processed samples; approved guideline: EP14-A3. 3rd ed. Wayne (PA): Clinical and Laboratory Standards Institute, 2014. 